\title{
NOTES ON YELLOW-SPOTTED MORAY EEL, ECHIDNA XANTHOSPILOS (ACTINOPTERY- GII: ANGUILLIFORMES: MURAENIDAE), FROM GREAT NICOBAR ISLAND, INDIA
}

\author{
M.P. GOUTHAM-BHARATHI*, Seepana RAJENDRA, and Chelladurai RAGHUNATHAN \\ Zoological Survey of India, Andaman and Nicobar Regional Centre, Port Blair - 744102, Andaman and Nicobar \\ Islands, India
}

Goutham-Bharathi M.P., Rajendra S., Raghunathan C. 2017. Notes on yellow-spotted moray eel, Echidna xanthospilos (Actinopterygii: Anguilliformes: Muraenidae), from Great Nicobar Island, India. Acta Ichthyol. Piscat. 47 (2): 209-212.

\begin{abstract}
A single specimen of Echidna xanthospilos (Bleeker, 1859) was captured off Great Nicobar Island. This finding represents a new addition to the muraenid fauna of India. This is one of the data-deficient species hitherto known only from five countries in the Indo-Pacific. The specimen is described and illustrated.
\end{abstract}

Keywords: fish taxonomy, fish morphology, new record, data-deficient species, Indian Ocean

The family Muraenidae (Anguilliformes), commonly known as moray eels, is one of the most abundant and diverse families of the true eels (Smith 2012). Morays occur worldwide in tropical and temperate seas, occurring from the shoreline to the edge of the continental shelf (Allen and Erdmann 2012, Smith 2012). They form a large and ecologically important component of the coral-reef habitat, where they inhabit holes and crevices, coming out to feed on a wide variety of fishes and invertebrates (Smith 2012).

The exact species composition of the family Muraenidae in the Andaman and Nicobar Islands is uncertain. According to Rajan et al. (2013), the Muraenidae is represented by 18 species assigned to 8 genera in the Andaman and Nicobar Islands. The genus Echidna Forster, 1788, characterized by the lack of canine teeth (Rao et al. 2000) is reported to be represented by five species in the islands (Herre 1941, Mishra and Krishnan 1996, Rao et al. 2000, Ramakrishna et al. 2010, Rajan et al. 2013, Arun Kumar et al. 2016, Rajendra and Raghunathan 2016). However, out of the five nominal species reported to be present in these islands, only three are valid viz., Echidna nebulosa (Ahl, 1789); Echidna polyzona (Richardson, 1845); and Echidna rhodochilus Bleeker, 1863 with the latter two being recent distributional records. While there has been an ambiguity in respect of "Echidna nigra (Day, 1870)" (reported by Herre 1941, Mishra and Krishnan 1996, Rao et al. 2000, Rajan et al. 2013) the other disputable species - "Echidna zebra (Shaw, 1797)" (reported by Herre 1941 and Rao et al. 2000) has been assigned to the genus Gymnomuraena Lacepède, 1803.
Marine faunal exploration in the Great Nicobar Island revealed the presence of the yellow spotted moray eel, Echidna xanthospilos (Bleeker, 1859), which is reported herein as a new distributional record to India from Andaman and Nicobar Islands.

During February 2016, a single specimen of Echidna xanthospilos was collected from the rocky intertidal zone at B. Quarry of Campbell Bay, Great Nicobar (Fig.1). The collected specimen was preserved in $10 \%$ formalin for further examination. The specimen was identified following Chen and Böhlke (1996), Böhlke et al. (1999), Allen and Erdmann (2012), and Eschmeyer et al. (2017). The methodology of measurements followed Böhlke and Randall (2000). Abbreviations of the cited collections:

RMNH = Rijksmuseum van Natuurlijke Historie

ZSI/ANRC $=$ Zoological Survey of India/Andaman and Nicobar Regional Centre

PU/DOSMB $=$ Pondicherry University/Department of Ocean Studies and Marine Biology

\section{Family MURAENIDAE \\ Echidna Forster, 1788}

Echidna xanthospilos (Bleeker, 1859)

Muraena xanthospilos Bleeker 1859: 348; Karangbollong (Karang-Bollong Bay, on north-eastern tip of Nusa Kambangan Island, $4.5 \mathrm{~km}$ southeast to Cilacap, Jawa Tengah Province, Java, Indonesia, eastern Indian Ocean, ca. $\left.7^{\circ} 45^{\prime} 34^{\prime \prime} \mathrm{S}, 109^{\circ} 02^{\prime} 32^{\prime \prime} \mathrm{E}\right)$; lectotype: RMNH 7210, 222 mm TL.

Specimen examined: a single specimen measuring $35 \mathrm{~cm}$ TL, ZSI/ANRC 13953, 12 February 2016, Andaman and 
Nicobar Islands, Great Nicobar, Campbell Bay, B. Quarry $\left(07^{\circ} 0^{\prime} 27.75^{\prime \prime} \mathrm{N}\right.$; $\left.93^{\circ} 56^{\prime} 44.66^{\prime \prime} \mathrm{E}\right)$, collected by Seepana Rajendra (Fig. 2).

Description: All proportional measurements were expressed as percentage of the TL and HL (Table 1). Body elongate, muscular, rigid and compressed; dorsal and anal fins confluent with caudal fin; pectoral and pelvic fins absent; tail shorter than pre-anal length; anterior nostril in short tube, near tip of snout, posterior nostril with slightly raised margin, above centre of eye, supraorbital pore adjacent to posterior nostril, gill opening in form of oblique slit, at mid-side; teeth molariform, first 4 dentary teeth larger, body depth at head $1.9 \mathrm{~cm}$ and at anus 2.4 $\mathrm{cm}$. Head pores typical, three super-orbital pores, four infra-obital pores, and six mandibular pores; two small branchial pores; eye wider than gill opening. Body colour dark brown with white or yellow ocelli, much larger than eye, and largest and of irregular form on abdomen; Colouration of live and preserved specimens not differing. Habitat: Shallow rocky inter-tidal zones and coral-reef habitats.

Distribution: Indo-Pacific: Taiwan, Sri Lanka, Indonesia, Papua New Guinea, and Samoa (Froese and Pauly 2016). Remarks: Hitherto not known from India; The presently reported finding constitutes a new distributional record of this fish to India from Great Nicobar Island, Andaman and Nicobar Islands.

Morays are notoriously difficult to deal with taxonomically because of their extreme variability and lack of unambiguous specific characters. The taxonomy of Indo-Pacific moray eels remains largely incomplete and is currently under study; some species are known only from a single inadequately described specimen, and many species are probably still undescribed (Böhlke et al. 1999). Echidna xanthospilos is one of the poorly known species of the family Muraenidae (Allen and Erdmann 2012,
Smith 2012) and has been known only from five countries in the Indo-Pacific (Froese and Pauly 2016). Following the recent records of congeneric species, E. polyzona (see Rajendra and Raghunathan 2016; Registration numbers: ZSI/ANRC 15270 and 15275) and E. rhodochilus (see Arun Kumar et al. 2016; Registration number: PU/ DOSMB/2010/2/1), E. xanthospilos is the fourth species to be reported from these Islands. Thorough exploration of this poorly known ichthyofauna is a pre-requisite to understand their diversity in Andaman and Nicobar Islands and to conserve them efficiently.

Table 1

Morphometric characters of Echidna xanthospilos from Great Nicobar Island

\begin{tabular}{lc}
\hline \multicolumn{1}{c}{ Character } & Value \\
\hline Total length (TL) & $35.00 \mathrm{~cm}$ \\
Head length & $16.00 \%$ in TL \\
Snout length & $2.28 \%$ in TL \\
Tail length & $45.71 \%$ in TL \\
Trunk & $38.57 \%$ in TL \\
Depth at gill opening & $12.85 \%$ in TL \\
Body depth at anus & $6.85 \%$ in TL \\
Pre-dorsal length & $11.71 \%$ in TL \\
Pre-anal length & $48.57 \%$ in TL \\
Head length (HL) & $5.60 \mathrm{~cm}$ \\
Inter-orbital space & $10.71 \%$ in HL \\
Length of upper jaw & $42.85 \%$ in HL \\
Length of lower jaw & $42.85 \%$ in HL \\
Snout length & $14.28 \%$ in HL \\
Eye & $1.78 \%$ in HL \\
Pre-orbital & $14.28 \%$ in HL \\
Post orbital & $83.92 \%$ in HL \\
Inter-orbital space & $10.71 \%$ in HL \\
\hline
\end{tabular}

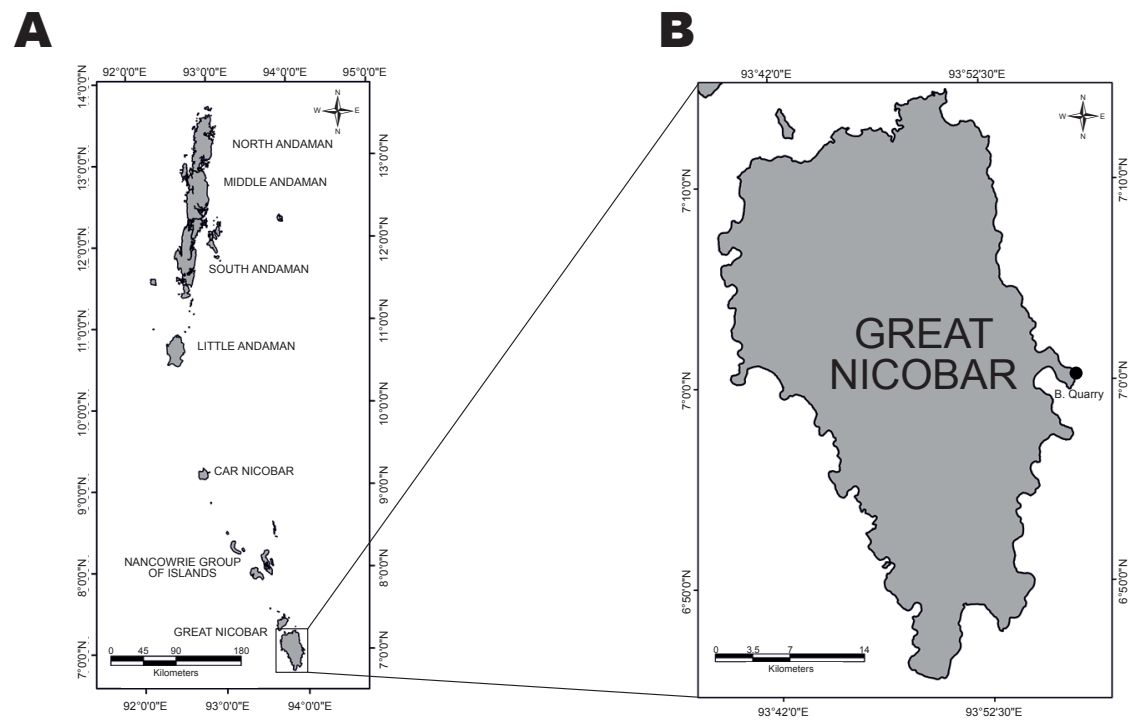

Fig. 1. Study area; Map of Andaman and Nicobar Islands (A); Great Nicobar Island (B) 


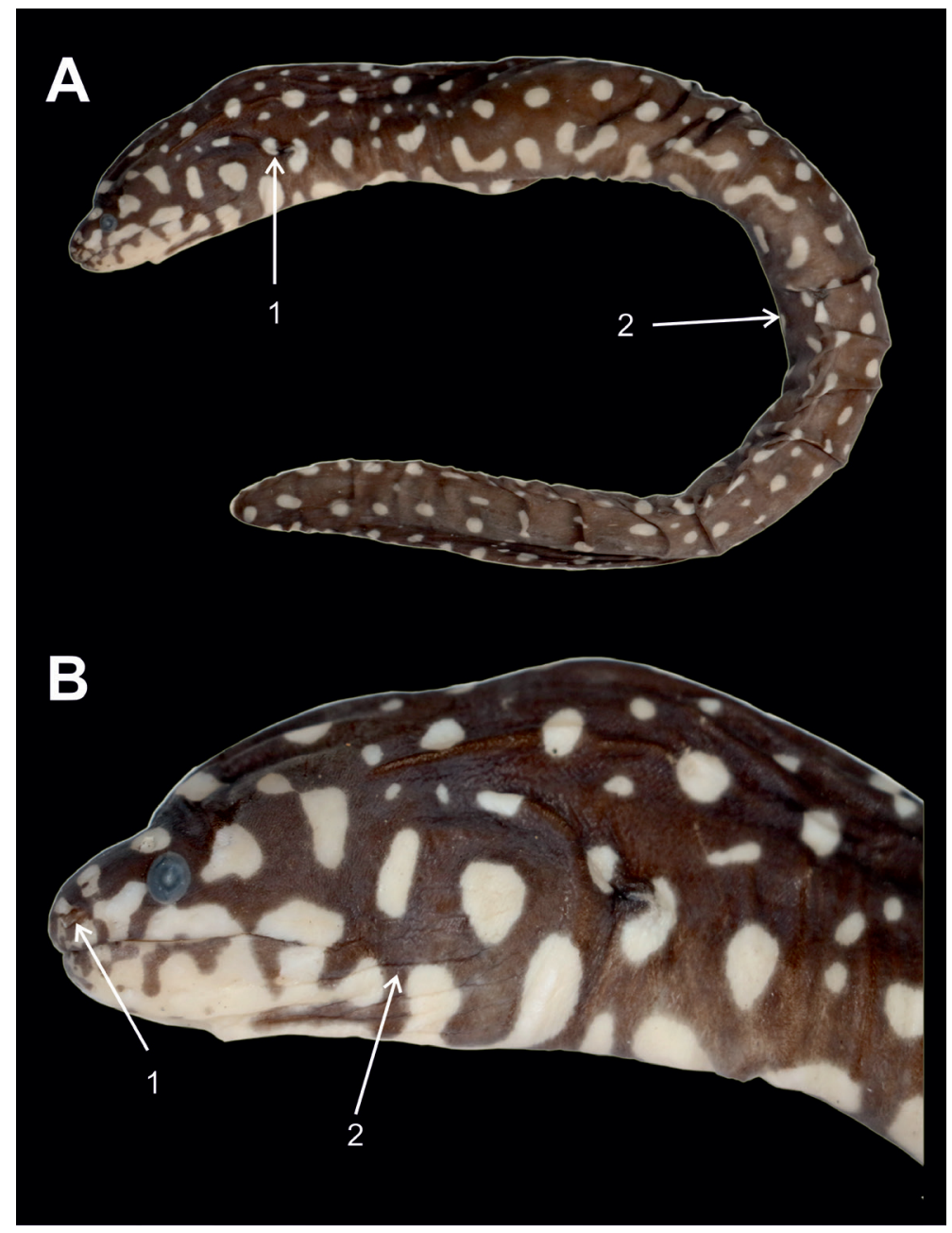

Fig. 2. Echidna xanthospilos (Bleeker, 1859) (TL $35 \mathrm{~cm}$ ) from Great Nicobar Islands. A = Preserved specimen: $1=$ gill opening, 2 = anal opening; $\mathbf{B}=$ head, lateral: $1=$ tubular nostrils, $2=$ branchial lines

\section{ACKNOWLEDGEMENTS}

The authors are grateful to Dr. Kailash Chandra, Director, Zoological Survey of India, Ministry of Environment, Forest and Climate Change, Government of India for the facilities and encouragement.

\section{REFERENCES}

Allen G.R., Erdmann M.V. 2012. Reef fishes of the East Indies. Volumes I-III. University of Hawai'i Press, Honolulu, HI, USA.

Arun Kumar M., Venu S., Padmavati G. 2016. First record of the pink lipped moray eel, Echidnarhodochilus (Bleeker 1863) (Family: Muraenidae), from Andaman and Nicobar Islands, India. International Journal of Oceanography 2016: article ID 6098027. DOI: $10.1155 / 2016 / 6098027$

Bleeker P. 1859. Over eenige vischsoorten van de Zuidkust-wateren van Java. [About some fish species of the southern coast of Java.] Natuurkundig Tijdschrift voor Nederlandsch Indië, Serie 4, 19 (5): 329-352. [In Dutch.]

Böhlke E.B., McCosker J.E., Smith D.G. 1999. Family Muraenidae. Pp. 1643-1658. In: Carpenter K.E., Niem V.H. (eds.) FAO species identification guide for fishery purposes. The living marine resources of the western central Pacific, Vol. III of Batoid fishes, chimaeras and bony fishes Part 1 (Elopidae to Linophrynidae). FAO, Rome.

Böhlke E.B., Randall J.E. 2000. A review of the moray eels (Anguilliformes: Muraenidae) of the Hawaiian Islands, with descriptions of two new species. Proceedings of the Academy of Natural Sciences of Philadelphia 150: 203-278.

Chen H.-M., Böhlke E.B. 1996. Redescription and new records of a rare moray eel, Echidna xanthospilos (Bleeker, 1859) (Anguilliformes: Muraenidae). Zoological Studies 35 (4): 300-304.

Eschmeyer W.N., Fricke R., van der Laan R. (eds.) 2017. Catalog of fishes: Genera, species, references. California Academy of Sciences, San Francisco, USA. http:// researcharchive.calacademy.org/research/ichthyology/ catalog/fishcatmain.asp [Accessed on 19 April 2017.]

Froese R., Pauly D. (eds.) 2016. FishBase. [Version 10/2016] www.fishbase.org

Herre A.W.C.T. 1941. A list of the fishes known from the Andaman Islands. Memoirs of the Indian Museum 13: 331-403. 
Mishra S.S., Krishnan S. 1996. Observations on the ichthyofaunal constituents restricted to the Indian subcontinental coastal waters. Records of the Zoological Survey of India 95 (3-4): 261-276.

Rajan P.T., Sreeraj C.R., Immanuel T. 2013. Fishes of Andaman and Nicobar Islands: A Checklist. Journal of the Andaman Science Association 18 (1): 47-87.

Rajendra S., Raghunathan C. 2016. First record of barred moray Echidna polyzona (Anguilliformes: Muraenidae) from Andaman and Nicobar Islands. Records of the Zoological Survey of India 116 (4): 63-66.

Ramakrishna, Immanuel T., Sreeraj C.R., Raghunathan C., Raghuraman R., Rajan P.T., Yogesh Kumar J.S. 2010. An account of additions to the ichthyofauna of Andaman and Nicobar Islands. Records of the Zoological Survey of India, Occasional paper No. 326.

Rao D.V., Kamla Devi, Rajan P.T. 2000. An account of the ichthyofauna of Andaman and Nicobar Islands, Bay of Bengal. Records of the Zoological Survey of India, Occasional paper No. 178.

Smith D.G. 2012. A checklist of the moray eels of the world (Teleostei: Anguilliformes: Muraenidae). Zootaxa 3474: 1-64.

Received: 15 February 2017

Accepted: 3 May 2017

Published electronically: 30 June 2017 